\title{
Together we can do more - environmental consciousness in the South African dam construction sector (1945-1980)
}

\author{
L VAN VUUREN ${ }^{1}$
}

\begin{abstract}
For several thousand years societies have diverted and dammed up rivers to meet their increasing water needs. The Industrial Revolution ushered in the modern era of water resource development, which has led to the construction of an estimated 50000 large dams worldwide.

Rising concerns over the state of natural resources following the Second World War resulted in the emergence of public anti-dam lobby groups who used protest and advocacy to place pressure on authorities to cease dam construction activities and improve environmental legislation. While these actions proved successful in many countries this approach has led to conflict between environmental groups and dam authorities.

South Africa is highly dependent on dams for stable and regular water supply. The country's 320 largest dams together store some $66 \%$ of the country's mean annual runoff. In contrast with the global environmental movement, institutionalisation of the environment occurred within the water engineering sector not as a result of outside pressures but due to rising concerns from water engineers themselves.

In the absence of strong adversarial environmental non-governmental organisations, improved management of the impact of large dams grew out of early cooperation between department officials and aquatic scientists, especially around the sustainable management of water resources in KwaZulu-Natal, as this article illustrates. This trend towards negotiation and collaboration led to the country's main developer of large dams, the Department of Water Affairs, instituting voluntary environmental policies from 1980.
\end{abstract}

Keywords: History, dams, rivers, history, environmental movement, environmental consciousness, water, aquatic science, engineering, cooperation

\section{Introduction}

Throughout the ages the lives of people and water have been inextricably linked. On a planet that is mostly covered in water, but where less than $2,5 \%$ of it is fresh, the ability of societies

Lani van Vuuren is a postgraduate student in History at North-West University's Vaal Campus. The article is based on an extended essay in 2012 and which was subsequently in 2013 submitted for an essay competition of postgraduate students in History at NWU's Potchefstroom and Vaal campuses. Ms Van Vuuren was the overall winner of the competition. 
to regulate and manipulate the water that is available to them have not only been key to their progress and development but to their very survival. ${ }^{2}$

While offering numerous benefits to society, such as water supply, hydroelectricity and flood control, the damming, diverting and canalisation of rivers over thousands of years have caused considerable damage to the freshwater environment, disrupting natural hydrological processes, and preventing the migration of fish and other aquatic species. It is estimated that large dams have regulated some $60 \%$ of the world's rivers to some extent. ${ }^{3}$ As many as 80 million people have had to leave their homes to make way for these artificial lakes. ${ }^{4}$

Led by the modern environmental movement, the often irreparable effects of water resource development on the receiving river system have increasingly been recognised from the sixties, leading to a rise in confrontations between state authorities and anti-dam lobby groups. ${ }^{5}$ This pressure has prevented the construction of further large dams in many countries, while improving environmental legislation in others.

Whereas countries such as the USA introduced legislation to mitigate the impact of water resource development from the seventies (i.e. the Environment Protection Act of 1970), the South African government, according to some environmental historians, remained seemingly apathetic towards environmental issues until the eighties. ${ }^{6}$

The country's racist policies caused it to be largely excluded from global environment-themed events prior to its democratisation in 1994, such as the United Nations Conference on the Human Environment, held in Stockholm in 1972..$^{7}$ Together with the lack of strong adversarial environmental non-governmental organisations that could place the necessary pressure on government, the isolation of South Africa is thought to have delayed institutionalisation of environmental matters. ${ }^{8}$

While this might seem the case when looking at the environmental sector as a whole, closer inspection of the South African water sector reveals that the charges of apathy and lack of institutionalisation may have been exaggerated, as this essay will illustrate. The focus here is on growing environmental consciousness in the South African water sector, with particular emphasis on large dam construction between 1945 and 1980. Case studies focus specifically

2. United Nations Environment Programme. 2008. Vital water graphics: An overview of the state of the world's fresh and marine waters, Second Edition. [Website: http://www.unep.org/dewa/vitalwater/article32.html] [Date of access: 14-03-2011].

3. World Wildlife Fund. Rivers at risk, dams and the future of freshwater ecosystems. Undated. [Website: http://awsassets.panda.org/downloads/riversatriskfullreport.pdf] Date of access: 07-03-2011.

4. World Commission on Dams (WCD). Dams and development: A new framework for decision making: The report of the World Commission of Dams: An Overview, p. 16.

5 . P. McCully, Silenced Rivers. The Ecology and Politics of Large Dams. Enlarged and Updated Edition, pp. 281-308.

6. See, for example, P. Steyn, 'Environmental management in South Africa: Twenty years of governmental response to the global challenge, 1972-1992' in Historia 46(1), 2001, pp. 25-53.

7. P. Steyn, 'Environmental management in South Africa: Twenty years of governmental response to the global challenge, 1972-1992' in Historia 46(1), 2001, pp. 25-53.

8. P. Steyn, 'Environmental management in South Africa: Twenty years of governmental response to the global challenge, 1972-1992' in Historia 46(1), 2001, pp. 25-53. 
on KwaZulu-Natal as an area where early environmental consciousness resulted in provincial authorities taking early action to protect natural water resources from over-exploitation.

In the absence of freshwater-oriented environmental groups, aquatic scientists, together with water engineers themselves, stepped forward to highlight environmental challenges in the South African hydrosphere from the forties. It is hypothesised that these scientists chose to work in collaboration with rather than against government water officials towards consensus and compromise towards the sustainable development of the country's water resources.

The essay explores the evolution of environmental awareness in the water resource development sector - more specifically within the Department of Water Affairs (DWA) as the country's main designer and builder of large dams. ${ }^{9}$ It identifies the main role-players and their relationship towards each other in dealing with environmental matters through a series of case studies. The study aims to show that cooperation between parties of conflicting interest can be successful in evoking change towards an improved environment.

\section{The need for dams in South Africa}

South Africa has a prolific history of dam development. This is despite the fact that the country was a relative late-comer to the modern dam construction boom when compared to developed countries such as the USA and Britain. While dam construction has slowed dramatically in the last two decades, the country still occupies the number six spot on the list of the International Commission on Large Dams (ICOLD), which ranks member countries according to their number of large dams. ${ }^{10}$ By 2012 a total of 4755 dams had been registered with the DWA Dam Safety Office (including medium large-sized dams). ${ }^{11}$

While pre-colonial society relied on more traditional storage methods, closer settlement by Europeans, particularly after 1652, relied on dams to create a more stable, regular supply. This is mainly due to the country's naturally variable climate and water resources.

South Africa's average annual precipitation is about $450 \mathrm{~mm}$ per annum (p/a) - well under the world average of $860 \mathrm{~mm}$ p/a. ${ }^{12}$ The country's semi-arid nature results in much water being lost to evaporation, and in many areas evaporation from the surface exceeds the average annual rainfall. ${ }^{13}$ As a result it is estimated that less than $9 \%$ of the precipitation that falls on the ground eventually finds its way into South Africa's river systems. ${ }^{14}$

9. A large dam is defined as being at least $15 \mathrm{~m}$ high from the lowest point of foundation or being between $5 \mathrm{~m}$ and $15 \mathrm{~m}$ high impounding more than 3 million $\mathrm{m}^{3}$.

10. International Committee on Large Dams (ICOLD). Number of dams by country members. Undated. [Website: http://www.icold-cigb.org/GB/World_register/general_synthesis.asp?IDA=206] [Date of access: 08-01-2013].

11. Department of Water Affairs (DWA). 2012. Dam Safety Office 2011/2012 Annual Report. [Website: http://www.dwaf.gov.za/dso/Documents/Annual\%20Report\%202011-\%2012\%20fin.pdf] [Date of access: 07-12-2012].

12. Department of Environmental Affairs \& Tourism (DEAT). South African Outlook. A report on the state of the environment, p. 145.

13. Department of Water Affairs (DWA), Water 75, p. 5.

14. L. Van Vuuren, 'Dam busters' in Africa Geographic (October), 2009, pp. 46-47.

TD, 9(1), July 2013, pp. 51-80. 
The country's water scarcity is illustrated by the fact that South Africa's total mean annual runoff is calculated at $49210 \mathrm{~m}^{3} /$ annum..${ }^{15}$ This is roughly equal to the total mean annual runoff of the Zambezi River to the north of the country. ${ }^{16}$ With a per capita water availability of only $1200 \mathrm{~m}^{3}$ per capita per annum, South Africa is considered a water scarce country. ${ }^{17}$

To overcome its climatic variability South Africa has historically depended on the construction of large dams to stabilise supply. These dams typically store two to three times the mean annual flow of the rivers in which they are constructed. ${ }^{18}$

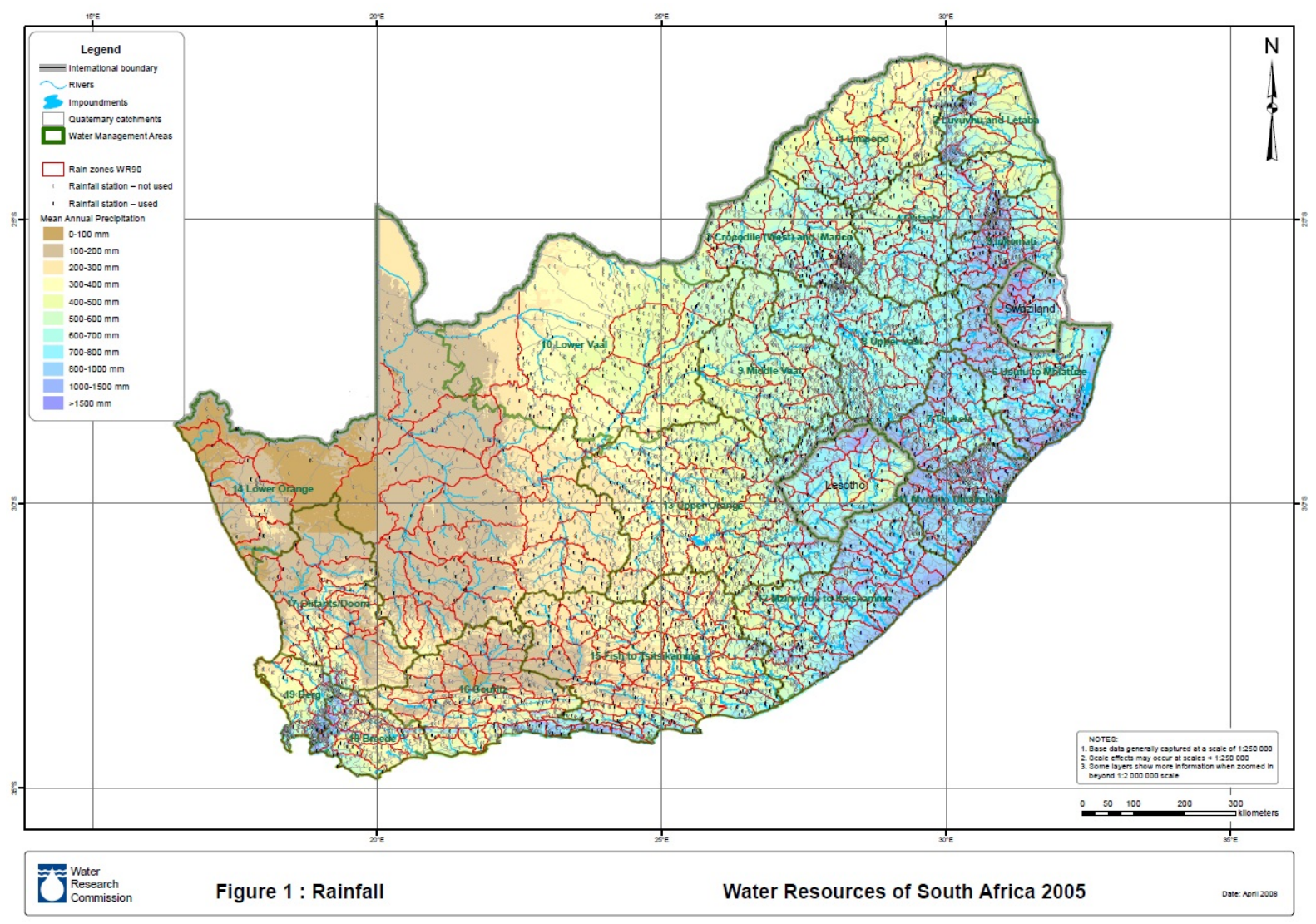

Illustration 1: Map showing distribution of rainfall in South Africa. ${ }^{19}$

15. B.J. Middleton and A.K. Bailey. Water Resources of South Africa, 2005 study (WR2005). Executive Summary Version 1, p. 15.

16. DWA. Water 75 , p. 7.

17. DEAT. South African Outlook. A report on the state of the environment, p. 435.

18. South African National Committee on Large Dams (SANCOLD). Large dams and water systems, $\mathrm{p}$. 46.

19. Map: Rainfall (2009), in B.J. Middleton and A.K. Bailey, Water resources of South Africa, 2005 study (WR2005) Book of maps version 1, figure 1, p. 28. 


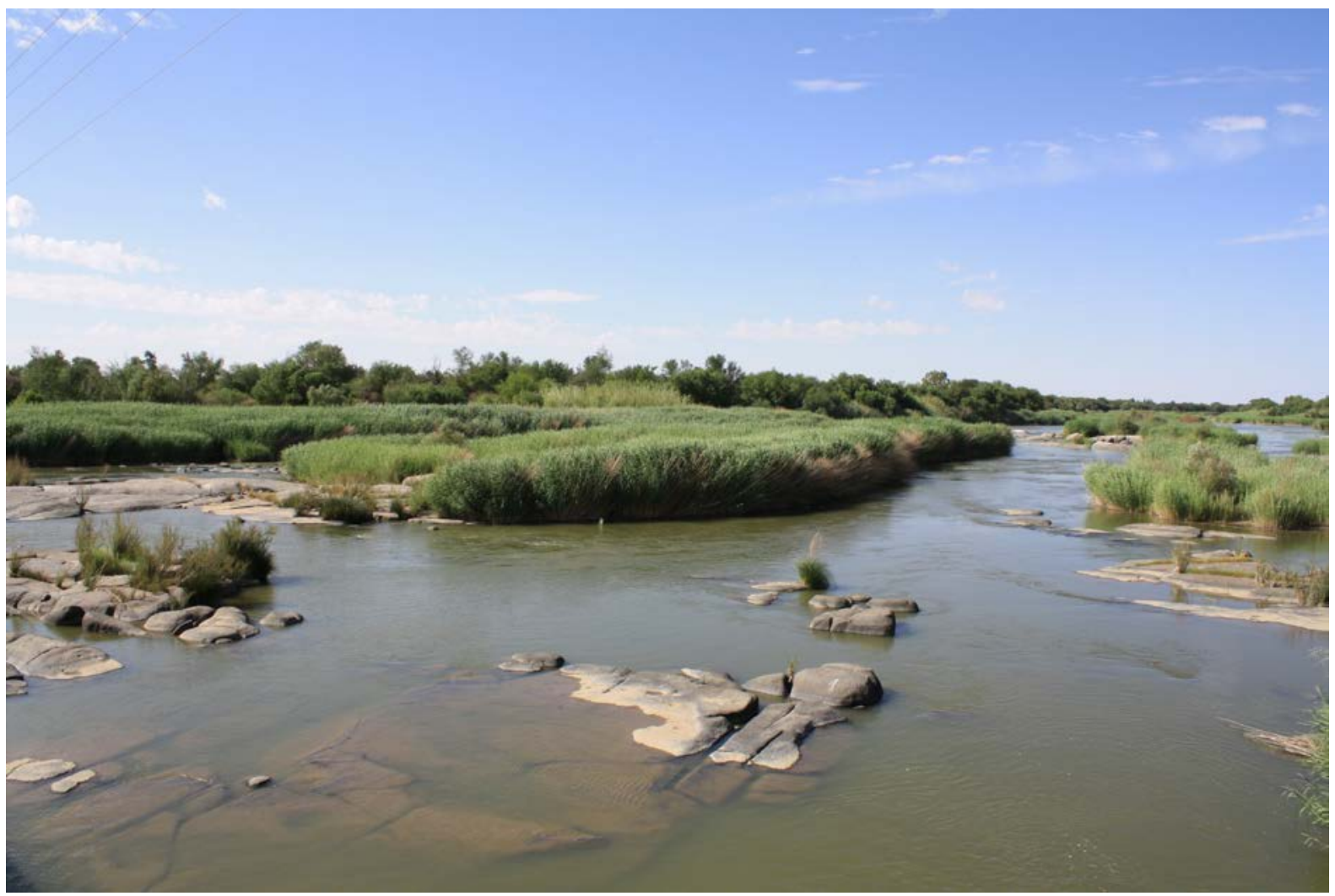

Illustration 2: The Orange River is South Africa's largest river, carrying 22\% of the country's total river flow. ${ }^{20}$

The first recorded modern dam was built in 1660 to supply water to Dutch trade ships travelling to and from the West Indies and held around $2000 \mathrm{~m}^{3}$ of water. ${ }^{21}$ As European settlers began to trek further inland over the next century the frontier expanded ever northwards and eastwards. Settlement was mostly concentrated around groundwater springs and a few perennial rivers. ${ }^{22}$ Springs were later dammed to provide water for livestock while furrows were led from streams to irrigate household gardens and small plots. ${ }^{23}$

In 1806, Britain annexed the Cape Colony as part of its growing colonial empire. The British brought with them some of their newly-found engineering expertise, including, it is hypothesised, the skill to dam rivers. By this time the dam construction sector was well established in Britain to serve the water and power needs of the Industrial Revolution. ${ }^{24}$

Early initiatives were instead taken by European missionaries. ${ }^{25}$ Robert Moffat led the construction of a dam at Dithakong in the 1820s, while by 1834 irrigation using furrows was

\footnotetext{
20. Photograph: L. van Vuuren, Kanoneiland, 18 Nov. 2010.

21. SANCOLD. Large dams and water systems in South Africa, p. 33.

22. W. Beinart. The rise of conservation in South Africa - Settlers, livestock and the environment, p. 88.

23. W. Beinart. The rise of conservation in South Africa, p. 89.

24. T. Turpin. Dam, p. 59.

25. L. Van Vuuren. In the footsteps of giants - Exploring the history of South Africa's large dams, p. 34.
} 
well established in the Kat River valley. ${ }^{26}$ Similar water leading infrastructure was constructed at the Moravian missions at Hemel-en-Aarde and Zuurberg. ${ }^{27}$

Dam construction gained impetus from the 1860s as a result of the first discoveries of diamonds at what became known as Kimberley in 1871 and then gold on the Witwatersrand in the early 1880s. New towns, such as Kimberley and Johannesburg - located close to mineral deposits rather than water resources - now required reliable water supply for thousands of newcomers searching for riches and glory, while the demand for foodstuffs found farmers applying innovative ways to improve their yield. ${ }^{28}$ One of the ways in which farmers sought to overcome the country's naturally erratic water supply was through the establishment of storage schemes.

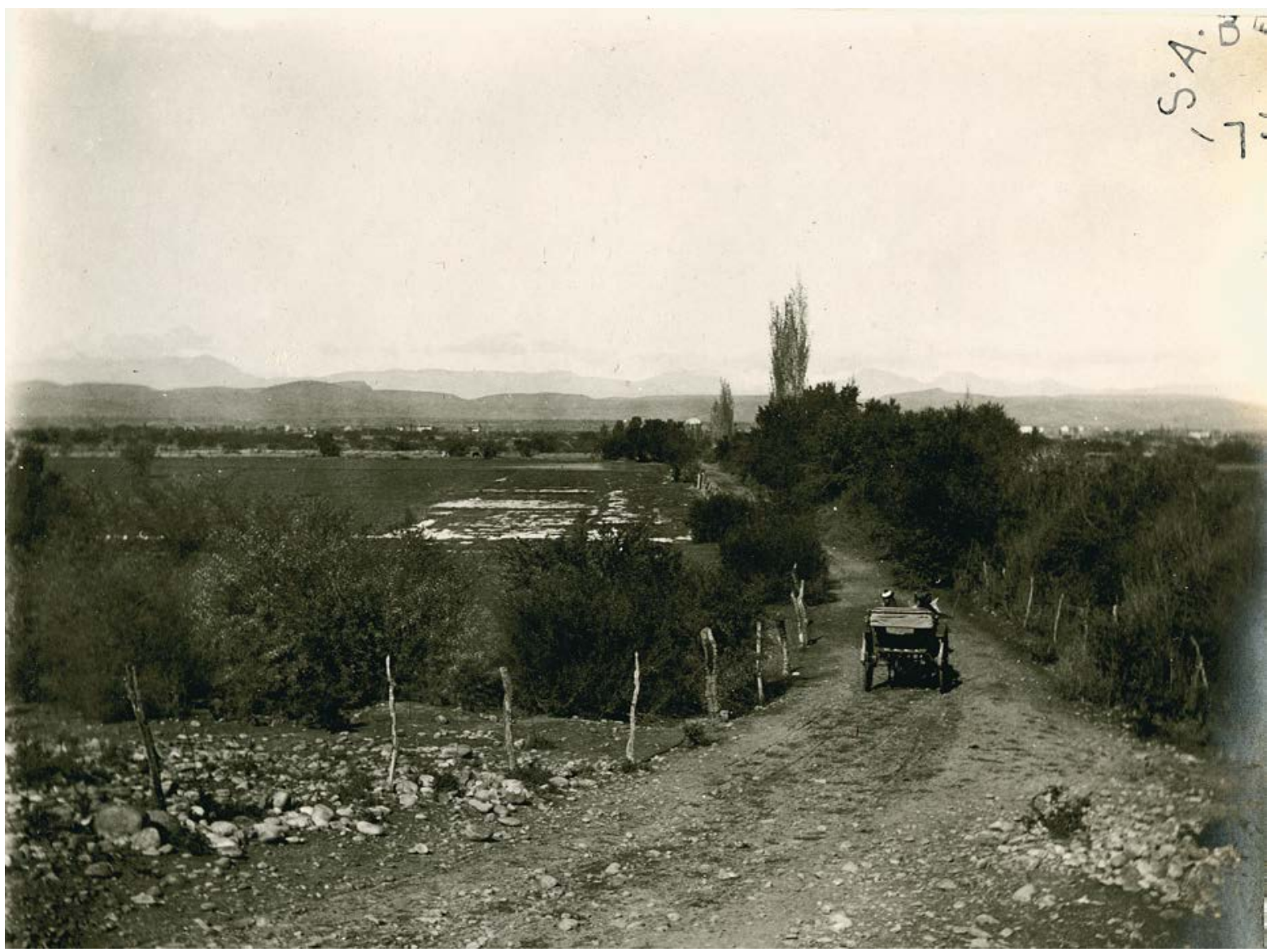

Illustration 3: The ostrich farm, Armoed, in the Oudtshoorn district, circa 1899. Flood irrigation can be seen on the left of the photograph. ${ }^{29}$

The Cape colonial government responded by appointing the country's first hydraulic engineer, John Gamble, in 1875, who dispersed engineering advice to municipalities and

\footnotetext{
26. W. Beinart. The rise of conservation in South Africa, pp. 90-91.

27. J.C. Brown. Water supply of South Africa and facilities for the storage of it, p. 472.

28. L. Van Vuuren. In the footsteps of giants, p. 36.

29. Photograph: National Library of South Africa, Cape Town collection.
} 
farmers alike. Many of his dam designs were later constructed. ${ }^{30}$ This was followed in 1877 by an Irrigation Act, which provided loans to farmers for water resource development for agricultural purposes as long as they organised themselves into so-called irrigation districts. ${ }^{31}$

The emergence of the ostrich feather export market to feed the fashion stores of Europe created further stimulus for the development of irrigation storage infrastructure. Birds were easier cared for when paddocked, but this meant their feed had to be supplemented, usually with lucerne. ${ }^{32}$ Initially flood irrigation was used to grow lucerne. This was later replaced by weirs and dams. ${ }^{33}$

Being mainly private investments these irrigation schemes generally remained small. There was early recognition that investment in water infrastructure in South Africa was expensive compared to countries such as India due largely to the country's geology and natural climatic and river characteristics, which made suitable dam sites scarce. ${ }^{34}$

After the South African War (1899-1902) the government increased its investment in irrigated agriculture - particularly through state-sponsored settlement schemes - in an effort to rebuild the country and settle both English soldiers and Afrikaner farmers who had lost their farms. ${ }^{35}$ When the Union was established, the irrigation departments of the Cape and Transvaal (established in 1904) merged. The Irrigation and Conservation of Water Act (No 9. Of 1912) was passed to further boost the development of dams.

Construction of several large dams started prior to the First World War. By 1925, 27 large dams had been built in South Africa, including Hartbeespoort Dam, Kamanassie Dam, Sundays River Dam, Lake Arthur, Grassridge Dam, and Tygerpoort Dam. ${ }^{36}$

In the latter part of the 1920s, the South African government instructed its departments dealing with infrastructure, including the Irrigation Department, to fast-track large government-sponsored public works projects, mainly to relieve poverty among the white minority amidst world economic depression and a nation-wide drought. ${ }^{37}$

30. L. Van Vuuren. In the footsteps of giants, pp. 38-39.

31. F.E. Kanthack. 'Irrigation development in the Cape Colony: Past, present and future' in Agricultural Journal of the Cape of Good Hope 36(3), 1910, pp. 645-657.

32. F.E. Kanthack. 'Irrigation development in the Cape Colony: Past, present and future' in Agricultural Journal of the Cape of Good Hope 36(3), 1910, pp. 645-657.

33. F.E. Kanthack. 'Irrigation development in the Cape Colony: Past, present and future' in Agricultural Journal of the Cape of Good Hope 36(3), 1910, pp. 645-657.

34 . F.E. Kanthack. 'Irrigation development in the Cape Colony: Past, present and future' in Agricultural Journal of the Cape of Good Hope 36(3), 1910, pp. 645-657.

35. L. Van Vuuren. In the footsteps of giants, p. 62.

36. 2009. SANCOLD. South African list of large dams. [Website:
[We http://www.sancold.org.za/index.php?option=com_content\&view=article\&id=64\&Itemid=74] [Date of access: 2013-01-07].

37. L. Van Vuuren. In the footsteps of giants, p. 105.

TD, 9(1), July 2013, pp. 51-80. 


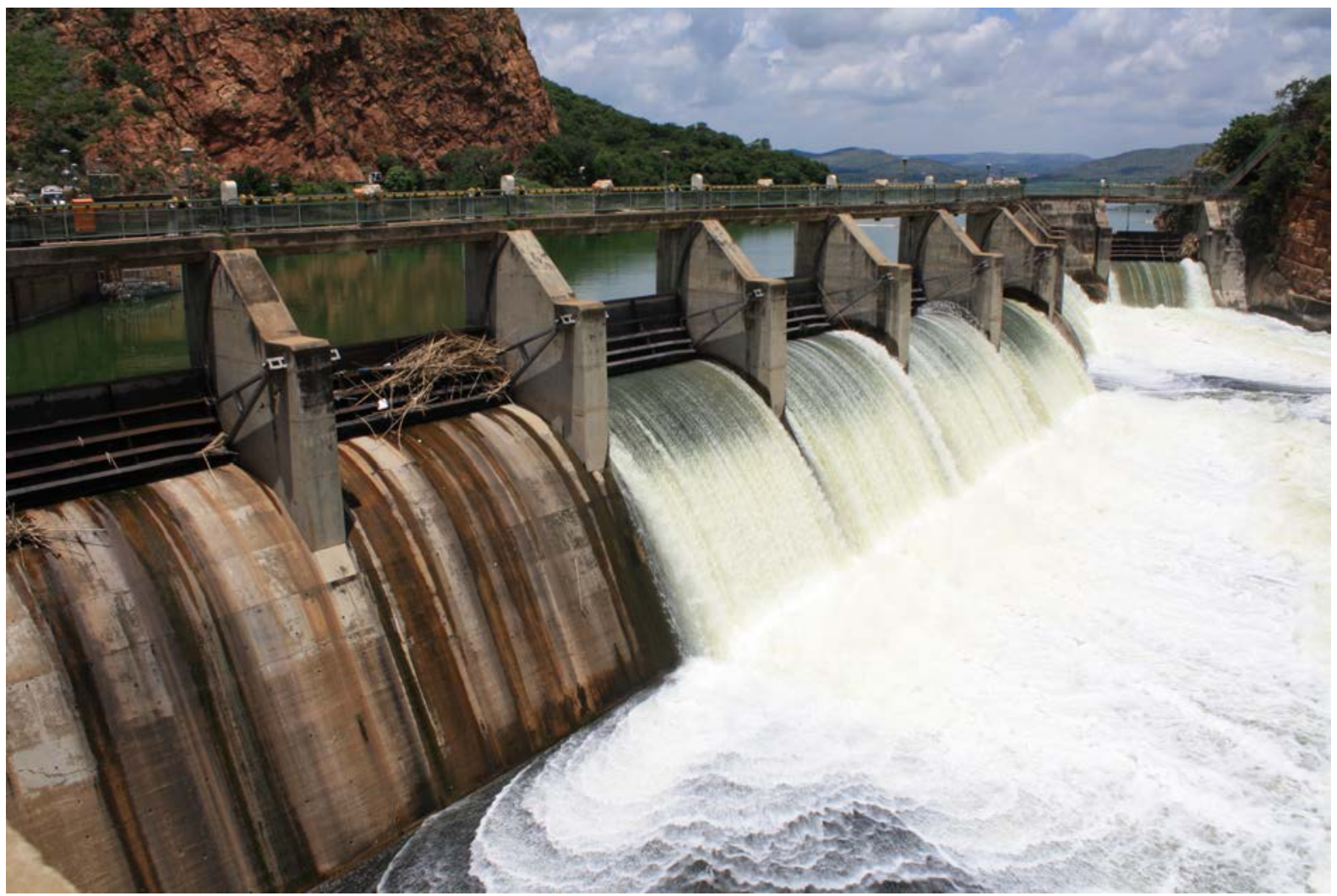

Illustration 4: The Hartbeespoort Dam was originally completed in 1923 and raised through the addition of sluices (pictured) in $1970 .{ }^{38}$

It is significant to note that at the majority of these schemes, including the largest (Vaalharts) and second-largest (Loskop) irrigation schemes in the country, manual labour was used almost exclusively. By 1938, expenditure on state water infrastructure had reached ten times the figure of $1928 .{ }^{39}$

In line with international trends, dam building reached a peak in South Africa in the postwar period. DWA undertook most of its own construction work and its construction department alone employed 20000 workers for this purpose (excluding department officials). ${ }^{40}$ By 1972, the DWA's annual expenditure on construction projects had reached R114 000 - three-and-a-half times the figure spent in 1932. ${ }^{41}$

As the DWA increased its scope of work to look beyond irrigation needs, large dams were now constructed as part of multi-purpose schemes, e.g. providing water for irrigation and power generation or industrial and domestic water use. ${ }^{42}$ This era of dam construction also witnessed a rise in inter-basin transfer projects - where water is transferred from catchments of surplus to feed catchments where water is in deficit.

\footnotetext{
38. Photograph: L. van Vuuren, Hartbeespoort Dam, 19 Jan. 2011.

39. $\quad$ DWA, Water 75 , p. 37.

40. L. Van Vuuren. In the footsteps of giants, p. 181.

41. DWA. Water 75, p.85.

42. DWA. Management of the water resources of the RSA, p. 1.10.
} 


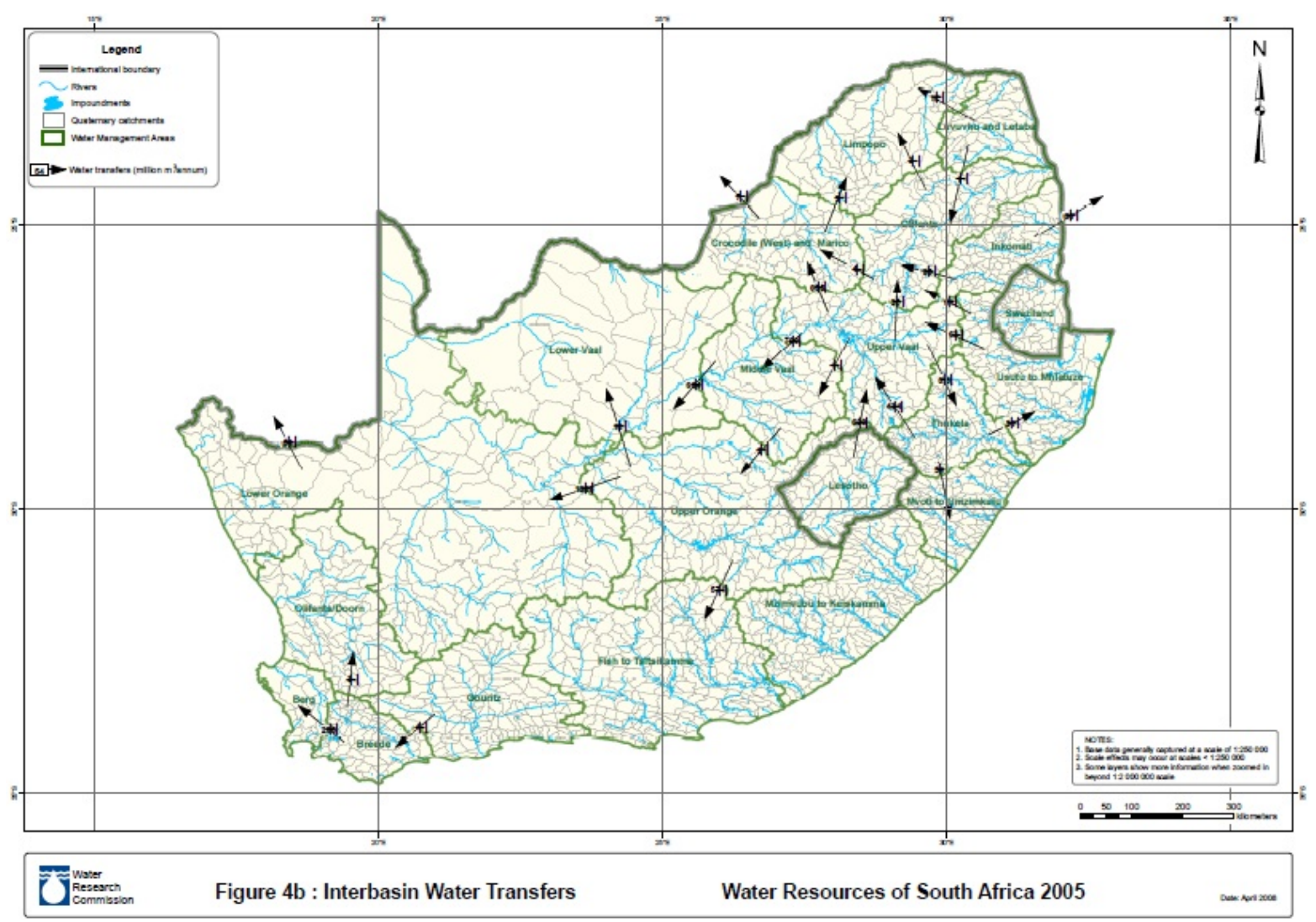

Illustration 5: Map showing the major inter-basin water transfer schemes in South Africa. ${ }^{43}$

Dam construction tapered off towards the end of the seventies, mainly as potential dam sites became fewer and dam construction became more expensive. The DWA's budget also became constrained as the South African government's attention turned to other matters, such as defence. ${ }^{44}$

Following democratisation in 1994, South Africa passed the National Water Act (No. 36 of 1998), which among others requires that enough water be reserved in the aquatic system for environmental and basic human purposes (known as the Reserve). ${ }^{45}$ The National Environmental Management Act (No. 108 of 1998) for the first time made environmental impact assessments and public scrutiny compulsory for all infrastructure development (including dams). ${ }^{46}$

Dams are no longer the first choice for water supply augmentation in South Africa. Instead the construction of further water resource development infrastructure is evaluated in each water supply region along a range of augmentation options, including (but not limited to)

43. Map: Inter-basin transfers schemes (2009), in B.J. Middleton and A.K. Bailey, Water resources of South Africa, 2005 study (WR2005) Book of maps version 1, figure 1, p. 71.

44. DWA. Management of the water resources of the RSA, p. 9.5

45. South Africa. 1998. National Water Act 36 of 1998. Pretoria: Government Printer

46. South Africa. 1998. National Environmental Management Act 107 of 1998. Pretoria: Government Printer 
water conservation/water demand management, water re-use, desalination and groundwater supply. ${ }^{47}$ Authorities are also considering the re-allocation of water from low-value to highvalue uses, for example, from agriculture to mining. ${ }^{48}$

\section{Large dams and the modern environment movement}

The Industrial Revolution gave rise to the modern era of dam construction. ${ }^{49}$ Dam building became prolific following the economic prosperity of the Second World War. Improved construction machinery and techniques allowed dams to be constructed faster, more economically and in difficult locations in nearly all parts of the world (including Africa). By 2010, there were an estimated 50000 large dams in the world..$^{50}$

A few isolated cases are reported in the nineteenth century, particularly in Britain and the USA, where parties with a conservation interest opposed the construction of large dams. ${ }^{51} \mathrm{An}$ oft reported case is the (unsuccessful) opposition by John Muir and conservation group, the Sierra Club, to a dam in the Hetch Hely valley in the early 1900 s. ${ }^{52}$

It was the post-Second World War period, however, which gave rise to the modern environmental movement as people became more concerned over the state of the world's natural resources, particularly as a result of overuse and pollution. Popular environmental publications by scientists, such as Rachel Carson's Silent Spring, alerted the public to the consequences of pollution and development. ${ }^{53}$

In the fifties anti-dam lobby groups successfully blocked the construction of a dam inside Dinosaur National Monument by the Bureau of Reclamation, in the US. The aggressiveness on the part of the non-governmental organisations and defensive stance of the Bureau led to a hostile relationship between the two parties that would set the tone for future confrontations. ${ }^{54} \mathrm{~A}$ similar adversarial relationship is also reported between environmental groups and the US Army Corps of Engineers. ${ }^{55}$

47 DWA. Integrated water resource planning for South Africa - A situation analysis 2010, pp. 6-7.

48. DWA. Assessment of the ultimate potential and future marginal cost of water resources in South Africa, p. 43.

49 . T. Turpin. Dam, p. 34.

50. ICOLD. Dams and the world's water. 2007. [Website: http://www.icoldcigb.org/userfiles/files/PUBLICATIONS/others/DWW-damsandworldwater.PDF] Date of access: 7-03-2011]

51. T. Turpin, Dam, p. 170.

52. T. Turpin, Dam, p. 173.

53. S. SOLOMON. 2010. Water - The Epic Struggle for Wealth, Power and Civilisation, pp. 354-355.

54. M.W.T. Harvey, 'Battle for Dinosaur: Echo Park Dam and the birth of the modern wilderness movement' in Montana: The Magazine of Western History 45(1), 1995, pp. 32-45.

55. M.C. Robinson, 'The relationship between the Army Corps of Engineers and the environmental community, 1920-1969' in Environmental Review 13(1), 1989, pp. 1-41. 
The introduction in the sixties and seventies of environmental assessment legislation and multi-disciplinary dam construction teams, which included landscape architects and ecologists, did not prevent the emergence of a highly politicised global anti-dam movement, which gained momentum from the eighties. ${ }^{56}$ This movement, led by political and humanrights activists, has been fuelled by the rise of environmentalism and have a strong political character. Anti-dam campaigns have mainly been in the form of media reports, mass action and demonstration. ${ }^{57}$

Starting as localised protests Anti-dam campaigns are now multinational and multiorganisational. ${ }^{58}$ A contemporary example is that of the Three Gorges Dam, in China, which has attracted significant international opposition.

Located in the Yangtze River, at $185 \mathrm{~m}$ high, the Three Gorges, completed in 2010, is the biggest dam in the world. ${ }^{59}$ The campaign against the construction of the dam has been led largely outside the borders of China by environmental activists in the US and Europe, with the millions of affected Chinese people themselves showing little involvement. ${ }^{60}$ Another example is opposition to India's Nermada project, which, while driven by local activists features strong international support. ${ }^{61}$ In Uganda, American-based non-governmental organisation, the International Rivers Network, drove protests against the Bujagali Dam, which eventually led to the project's abandonment, in spite of local communities seemingly supporting the project. ${ }^{62}$

A milestone in the history of large dams was the establishment in 1998 of the World Commission on Dams (WCD) to provide a global overview of the benefits and impacts of large dams. The commission was chaired by former South African Minister of Water Affairs \& Forestry, Prof Kader Asmal. ${ }^{63}$ The Commission's final report, published in 2000, provides recommendations to improve environmental management around large dams going forward. ${ }^{64}$ Several countries have adopted these guidelines or derivatives thereof, including South Africa, although the application of WCD guidelines remains voluntary.

For ten years after the WCD final report was published dam construction came to a virtual halt in developed countries, with large internationally funding agencies such as the World

56. T. Turpin, Dam, p. 225.

57. D.L. Sills, 'The environmental movement and its critics' in Human Ecology 3(1), 1975, pp. 1-41.

58. P. McCully, Silenced Rivers, p. 21.

59 . Y.B. Lee, 'Global capital, national development and transnational environmental activism: Conflict and the Three Gorges Dam' in Journal of Contemporary Asia 43(1), 2013, pp. 102-126.

60. Y.B. Lee, 'Global capital, national development and transnational environmental activism: Conflict and the Three Gorges Dam’ in Journal of Contemporary Asia 43(1), 2013, pp. 102-126.

61. A. Gandhi. 'Developing compliance and resistance: The state, transnational social movements and tribal peoples contesting India's Narmada project' in Global Networks 3(4), 2003, pp. 481-495.

62. S. Mallaby. 2004. NGOs: Fighting poverty, hurting the poor, Foreign Policy, 1 September. [Website: http://www.foreignpolicy.com/articles/2004/09/01/ngos_fighting_poverty_hurting_the_poor] [Date of access: 19-06-2012].

63. T. Turpin. Dam, p.205.

64. WCD. Dams and development, p. xx.

TD, 9(1), July 2013, pp. 51-80. 
Bank withdrawing its support to large dam developments. In the last year, however, the global movement towards greener technologies have re-awakened interest in large dams, particularly for hydropower generation as an alternative to the use of fossil fuels. ${ }^{65}$

\section{The awakening of environmental consciousness in the South African dam sector}

Like many other countries where large dams have been constructed, South Africa is paying the price for the socio-economic benefits reaped from its large dams by way of environmental impacts. The South African National Committee on Large Dams (SANCOLD) summarises the main environmental impacts of large dams on river systems in the country as follows:

- Loss of arable land, natural habitats, human settlement and archaeological sites in reservoir basins;

- Water quality changes in the impounded water body in terms of physical, chemical and biological characteristics;

- Water quality changes in the river reaches immediately downstream of the dam in terms of physical, chemical and biological characteristics;

- Modifications to the river morphology and flow patterns in the downstream river reaches; and

- Modifications to the riverine ecosystems in the river reaches that flank the reservoir both upstream and downstream. ${ }^{66}$

In line with international trends South Africa's water resources received more attention from 1944 as serious concern was expressed regarding the apparent deteriorating water quality in several areas due to pollution. In that year a committee was appointed by the Minister of Welfare and Demobilisation to

\section{(Make an) (e)nquiry into, report on and make recommendations in connection with, incidence through the Union of bacterial and chemical pollution of water suppliers used or which may be used for domestic purposes for water supplies, including livestock in both urban and rural areas. ${ }^{67}$}

At that stage limited legislation pertaining to the protection of the country's water against pollution were contained in the Public Health Act of 1919, the Irrigation Act of 1912, and the Gold Law Act of 1908. Provincially, the Cape and Natal had passed ordinances to protect their fish populations. ${ }^{68}$ However, it was municipalities who were mostly responsible for acting against polluters. ${ }^{69}$

65. J.I.A. Jinsheng. Summary Report as ICOLD President: Joint efforts for better development of dams and reservoirs, May 31 2012. [Website: http://www.icold2012kyoto.org/pdf/]iaOpening.pdf] [Date of access: 03-02-2013]

66. SANCOLD. Large dams and water systems in South Africa, p. 178.

67. SAB, GES, 107/33 2069. Report of the Committee of Enquiry on Bacterial and Chemicals Pollution of Water supplies, undated.

68. SAB, GES, 107/33 2069. Committee of Enquiry on Bacterial and Chemicals Pollution of Water supplies, undated.

69. SAB, GES, 107/33 2069. Committee of Enquiry on Bacterial and Chemicals Pollution of Water supplies, undated. 
Members of the committee included representatives from the departments of health, irrigation, and agriculture. ${ }^{70}$ The committee expressed its concern over the lack of research on South African rivers, the widespread pollution of the country's scarce water resources, and called for the 'determined efforts' to prevent 'undue pollution' of South Africa's water. ${ }^{71}$

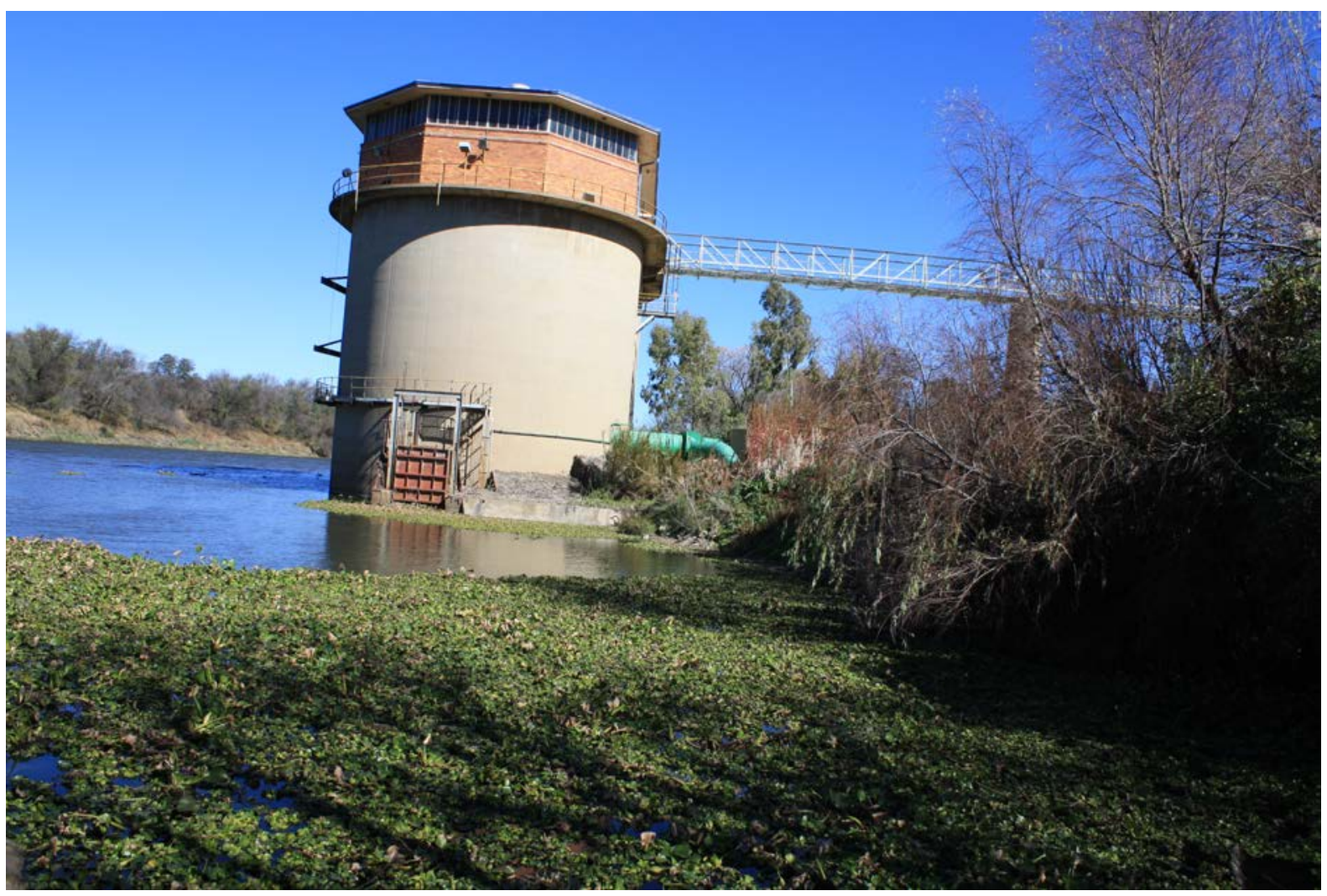

Illustration 5: Hyacinth in the Vaal River at the Midvaal Water intake in 2009. ${ }^{72}$

The committee also pointed to the lack of water quality research in South Africa's rivers and dams. Water quality problems, such as eutrophication in the Vaal River following the construction of the Vaal Dam, had been reported from the thirties. ${ }^{73}$

It was not only authorities who became increasingly concerned over the deterioration of South Africa's water resources. From 1945 the engineering fraternity in South Africa was publicly voicing its concerns over the effect of water pollution on the country's aquatic

70. SAB, GES, 107/33 2069. Committee of Enquiry on Bacterial and Chemicals Pollution of Water supplies, undated.

71. SAB, GES, 107/33 2069. Committee of Enquiry on Bacterial and Chemicals Pollution of Water supplies, undated.

72. Photograph: L. van Vuuren, Water hyacinth in Vaal River, 13 Jul. 2009.

73 C.A. Bruwer. The economic impact of eutrophication, p. 3.

TD, 9(1), July 2013, pp. 51-80. 
wildlife. ${ }^{74}$ It was seen as the engineer's duty to ensure the protection of South Africa's water resources, not only for the sake of people, but also for the sake of the environment. ${ }^{75}$

Through forums such as the South African Institution of Civil Engineers (SAICE) water engineers discussed the need for improved regulation to curb pollution and better regional development planning to prevent the over-allocation of water resources. SAICE President and Irrigation Department Director A.L. Mackenzie was particularly outspoken over his concerns regarding the direction in which South Africa's water resources was heading. In his 1944 presidential address he called for improved management of the country's water resources, particularly where the planning of new water infrastructure was concerned. ${ }^{76}$

Mackenzie also initiated enquiries into the country's water laws and the activities of his department, as he felt the focus was too narrowly placed on irrigation, with not enough attention being afforded to other water demands. ${ }^{77}$ Following a commission of enquiry into South Africa's water law the Irrigation Act of 1912 was replaced with the Water Act (Act 54 of 1956)..$^{78}$ The Act included for the first time some measure of pollution control mainly aimed at discharges of effluent from industry. ${ }^{79}$

In the early fifties freshwater research programmes, such as the river research programme of the Natal Town and Regional Planning Commission highlighted the state of quality of the country's water resources and the need to take action. Up until that time most aquatic research in South Africa was focused on the identification and classification of aquatic species. ${ }^{80}$

The main objectives of commission's Natal Rivers Research Fellowship were to obtain a better understanding of the origin and characteristics as well as the state of water quality in Natal's main rivers, especially after routine surveys discovered far-reaching river pollution by industries and mines. ${ }^{81}$

74. G.J. Stander. 'The quality requirements of water for the maintenance of aquatic flora and fauna and for recreational purposes' in The South African Industrial Chemist 6(6) 1952, pp. 118-119.

75. N. Shand. 'The role of the civil engineer in the daily life of the community' in The Transactions of the SAICE 3(12), 1953, pp. 381-391.

76. A.L. Mackenzie. 'Presidential address' in Minutes of Proceedings of the South African Institution of Civil Engineers (SAICE) 47, 1949, pp. 6-26.

77. Union of South Africa. Report of the Director of Irrigation for the period 1 April, 1940 to 31 March, 1946. (Report No. UG 55-1947, Government Printer: Pretoria)

78. DWA. Management of the water resources of the RSA, p. 8.8 .

79. DWA. Management of the water resources of the RSA, p. 8.17.

80. P. Ashton, D. Roux, C. Breen, J. Day, S. Mitchell, M. Seaman, and M. Silberbauer. The freshwater science landscape in South Africa, 1900-2010, Overview of research topics, key individuals, institutional change and operating culture, p. 1.

81. SAB, WW, Pretoria, K52/4/1 435. Letter from Administrator of Natal to J.J. Fouché, Minister of Agricultural Technical Services and of Water Affairs, 7 July 1966 regarding abatement of pollution in rivers in Natal. 


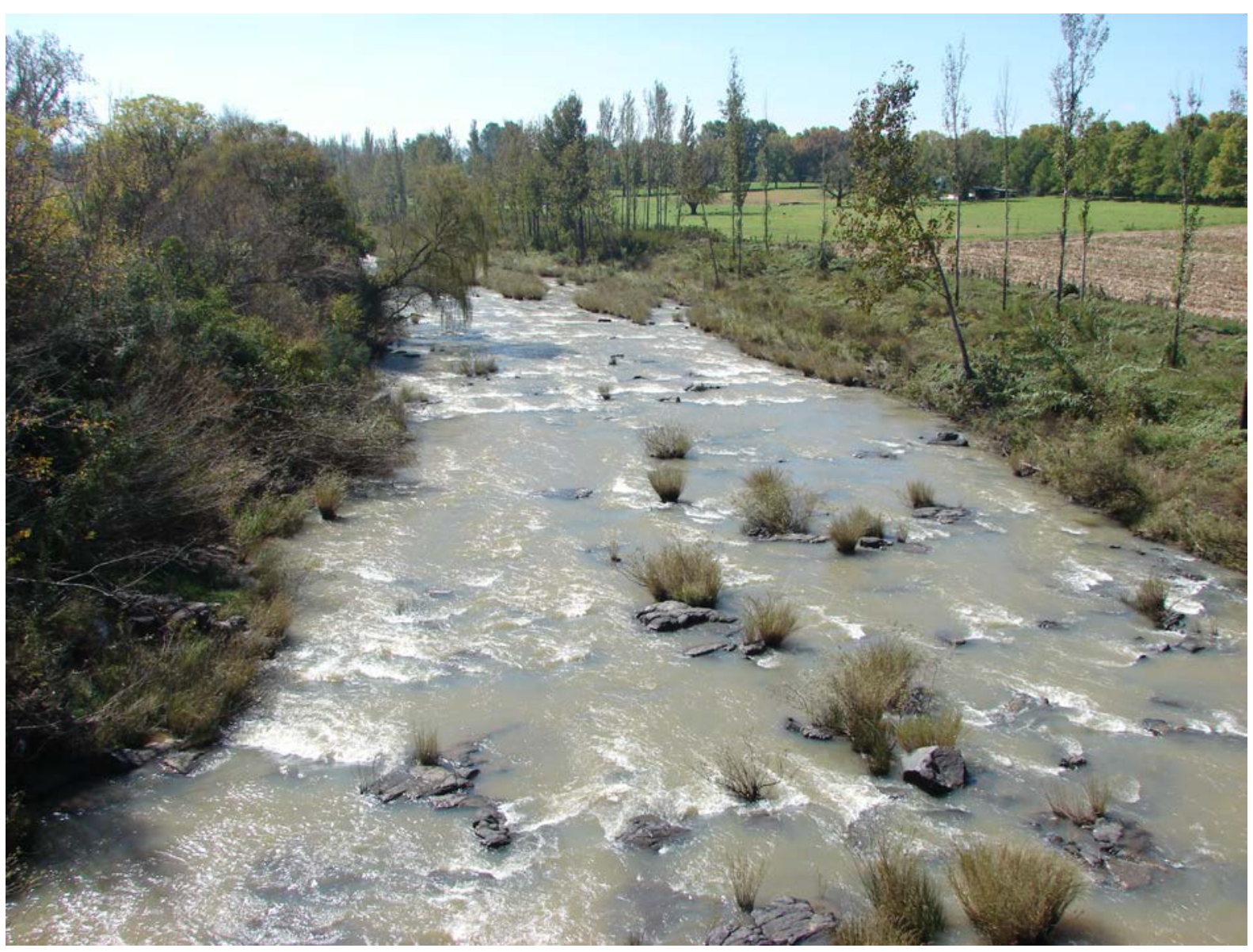

Illustration 12: The Tukhela River in KwaZulu-Natal was one of the first rivers on which hydrobiological studies were undertaken in South Africa under the Natal Rivers Research Fellowship. ${ }^{82}$

By 1965, the Natal Rivers Research Fellowship had covered some 46\% of Natal and Zululand. ${ }^{83}$ A particularly important discovery made through the programme was the fact that communities of aquatic plants and animals were found to be sensitive to alterations in water quantity and quality. This would later become one of the main indicators of river health in South Africa, especially in the DWA River Health Programme, established after 1998.

An important aspect of these programmes was that results were generally considered confidential and reports were not distributed publically. This might explain why the South African public seemed generally apathetic towards the freshwater environment. Established organisations such as the Wildlife Society of Southern Africa and the Botanical Society of South Africa were more concerned over the country's fauna and flora than over its freshwater resources. ${ }^{84}$ These organisations also chose to work with the government, rather than to oppose it.

82. Photograph: L. Van Vuuren, Tukhela River, 08 Apr. 2006.

83. SAB, WW, Pretoria, K52/4/1 435. Water quality and abatement of pollution in Natal rivers, undated, p.2.

84. P. Steyn. 'Popular environmental struggles in South Africa' in Historia 47(1), 2002, pp. 125-158. 


\subsection{Involvement in international communities}

While South Africa became increasingly isolated after 1960 as a result of its political activities, both its scientific and engineering communities benefited from global interactions with professional bodies. Despite being barred from attending meetings in certain countries aquatic scientists and water engineers were nevertheless exposed to the international environmental movement and discussions around dams and river ecosystems. ${ }^{85}$

Apart from contributing to international research programmes aquatic scientists were also able to share the results of findings from South African freshwater studies through articles in international journals, the most popular of which was Hydrobiologia and the African Journal of Aquatic Sciences.

For South Africa's water engineers the country's membership of ICOLD, which it joined in 1965, proved crucial in moulding their thinking around the environment and dams. South Africa participated actively in ICOLD activities, with DWA senior officials (along with private engineers) regularly attending meetings and conferences and contributing to technical committees. ${ }^{86}$ Although South Africa did not serve on the ICOLD environmental committee which was established in 1972 as a direct result of the United Nations Conference on the Human Environment, technical reports dealing with environmental matters were widely distributed among DWA engineers. ${ }^{87}$ Environmental awareness was also ingrained into the DWA culture.

In 1976, the country assumed a leadership role in ICOLD when Secretary of Water Affairs, Dr Jaques Pierre Kriel, was elected Vice President of ICOLD. Kriel was a campaigner for cooperation between engineers and other science disciplines, including ecological scientists. ${ }^{88}$ He believed that environmental studies prior to the construction of dams were essential so as to ensure that dams would not bring more impacts than benefits to communities, and he called on engineers to take more responsibility for the impact their developments had on the surrounding environment. ${ }^{89}$

For Kriel the only way forward to achieve a balance between the protection of the environment and meeting the needs of a growing population was through compromise. As the head of the government's water department he would have had a considerable influence over government policy, and ensured the DWA's participation in and funding of multidisciplinary collaborative freshwater research programmes, as will be described below.

85. VVPA, Folder 4. 20120213 King, p. 2 of pp. 1-3 and VVPA, Folder 4, 20101123 Van Robbroeck, p. 4 of pp. 1-7.

86. VVPA, Folder 4, 20120621 Van Robbroeck, p. 1 of pp. 1-3.

87. VVPA, Folder 4, 20120621 Van Robbroeck, p. 1 of pp. 1-3.

88. J.P. Kriel. 'Die siviele ingenieur in die veranderende wêreld' in The Civil Engineer in South Africa 14(4), 1972, pp. 141-151.

89. J.P. Kriel. 'Die siviele ingenieur in die veranderende wêreld' in The Civil Engineer in South Africa 14(4), 1972, pp. 141-151. 
Even before he became Secretary of Water Affairs Kriel led a major study into the impacts of proposed dam development on the St Lucia lake system between 1963 and 1967. A Committee of Enquiry was established after concerns were expressed by the scientific community over potential impacts of the new Hluhluwe dam on St Lucia's water supply. ${ }^{90}$

This is after an earlier study on the ecology of the St Lucia system pointed to increasing siltation and salinity problems in the freshwater system as a result of both natural processes and human actions. ${ }^{91}$ It was thought that another dam would worsen the situation.

The commission investigated several threats to the St Lucia system including the impacts of dam construction on the rivers feeding the wetland system. The final report of the commission, published in 1967, proposed that for every storage dam constructed in future in the catchment a proportion of the yield should be reserved for supply to the system during dry periods. ${ }^{92}$ The commission went so far as to suggest that dams be especially built for St Lucia to guarantee its supply during dry periods.

The results of the St Lucia commission would later influence the findings of the Commission of Enquiry into Water Matters, which was published in $1970 . .^{93}$ This was the first official document in which the need to allocate water for the environment was expressed, in this case for two of the country's most iconic nature reserves, namely Lake St Lucia and the Kruger National Park. ${ }^{94}$ Although aquatic scientists would not agree with the figure of $1 \%$ of the total estimated water consumption to be set aside for freshwater ecosystems as suggested by the commission, it provided a useful point of departure for further debate and study in the early eighties. The finding of the Commission of Enquiry into Water Matters served as the foundation for the 1998 Reserve legislation. ${ }^{95}$

\subsection{Cooperative research programmes}

Aquatic research in South Africa received a major boost through the country's involvement in the International Biological Program (IBP), which was launched by the International Council of Scientific Unions (ICSU) in 1964. ${ }^{96}$ The IBP focused on research that investigated man's relationship with his environment, and over the next decade projects were funded in 60 countries around on seven themes (including freshwater), the ultimate objective

90. See for example K1/8 Vol III 12. Letter to the Private Secretary to the Minister of Lands from the South African Association for the Advancement of Science, 2 February 1963.

91. J.H. Day, N.A.H. Millard and G.J. Broekhuysen, 'The ecology of South African estuaries Part IV: The St Lucia system' in Transactions of the Royal Society of South Africa 34(1), 1954, pp. 129-156.

92. J.P. Kriel. Report of the Commission of Inquiry into the alleged threat to animal and plant life in St Lucia Lake, p. 186.

93. Republic of South Africa. Report of the Commission of Enquiry into water matters. (Report No. RP 34-1970z, Government Printer: Pretoria, 1970).

94. R.D. Walmsley and B.R. Davies. 'An overview of water for environmental management' in Water $S A$ 17(1), 1991, pp. 67-76.

95. J. King and H. Pienaar (Eds.). Sustainable Use of South Africa's Inland Water, p. 59.

96. P. Ashton, et al. The Freshwater Science Landscape in South Africa, 1900-2010, p. 10.

TD, 9(1), July 2013, pp. 51-80. 
being to use the results from these projects to make recommendations for the improvement of society's well-being. ${ }^{97}$

In 1970, ICSU established the Scientific Committee on Problems of the Environment (SCOPE) to further drive international research in the environmental field. As a result of the successful participation of South African researchers in this programme as well as the IBP, a number of national collaborative research programmes were established, most notably the National Programme for Environmental Sciences (NPES) under the auspices of the Council for Scientific and Industrial Research (CSIR) in 1972. The NPES was a substantive programme, involving at its height over 300 scientists from various disciplines. ${ }^{98}$ For this discussion the most important sub-programme of the NPES was the multidisciplinary, cooperative, Inland Water Ecosystems (IWE) programme, which was aimed at

\section{the promotion, coordination and...initiation of research relating to environmental problems and the utilisation and conservation of inland water ecosystems. ${ }^{99}$}

More specifically, the IWE programme sought to investigate existing and projected impacts on the aquatic environment by anthropogenic actions and finding solutions for these problems. ${ }^{100}$ During the first decade of the programme the main focus of research was solving environmental problems experienced in man-made water systems, such as eutrophication and sedimentation in dams. ${ }^{101}$ Later the emphasis would shift to incorporate more catchmentorientated research. Funding came from government departments, research bodies such as the CSIR and the Water Research Commission (WRC), as well as the Council for the Environment (and later the departments of Water and Environmental Affairs).

Information sharing was an important part of the IWE programme. The programme was administered by the National Committee for Environmental Sciences, which among others included representatives from the DWA, the Department of Health and the Environment, provincial administrations, the WRC, the CSIR, provincial administrations and participating universities. ${ }^{102}$ In turn, smaller, technical committees with representatives from different disciplines and stakeholder groups gathered regularly in meeting rooms, at symposia and workshops and during field visits to discuss environmental problems, the outcomes of research projects and the way forward. ${ }^{103}$

97. Anon. 'The International Biological Programme' in South African Medical Journal 45(45), 1971, p. 1277 .

98. Ecosystems Programmes (Compiler). Environmental research perspectives in South Africa, p. 2.

99. R.G. Noble and J. Hemens. Inland water ecosystems in South Africa - A review of research needs, p. iv.

100 R.G. Noble and J. Hemens. Inland water ecosystems in South Africa - A review of research needs, $p$. iv.

101 . R.D. Walmsley. 'The role of multidisciplinary research programmes in the management of water resources' in Water SA 18(2), 1992, pp. 195-201.

102. R.G. Noble and J. Hemens. Inland water ecosystems in South Africa, p. 3.

103. R.D. Walmsley. 'The role of multidisciplinary research programmes in the management of water resources' in Water $S A$ 18(2), 1992, pp. 195-201. 
As scientist R.D. Walmsley points out, the IWE programme was instrumental in 'initiating, stimulating and coordinating research' between multidisciplinary parties from different organisations - particularly aquatic scientists and water engineers. ${ }^{104}$ Given the legislative and policy environment of South Africa's water sector at the time it is unlikely that any other forum could have been as successful in bringing people from these different sectors together to discuss water-related issues. Equally important is the fact that the programme emphasised the environmental impacts of dams in a scientific rather than in an alarmist manner, which resulted in an improved likelihood of buy-in from decision-makers.

South Africa's aquatic science community begrudgingly accepted the country's dependence on dams:

We have to use rivers. We have to dam them and, in so doing, we inevitably alter the characteristics of rivers: their flow rate, their volume and their temporal features, their temperature, erosive nature, particulate material and their chemistry. ${ }^{105}$

Rather than opposing government dam construction schemes scientists chose to work with decision-makers in order to come to some kind of compromise. This collaborative approach had a positive outcome. R.D. Walmsley comments thus on the value of the programme:

Sound management of aquatic ecosystems requires an understanding of their ecological functioning. Very few of the IWE sub-programmes failed to meet their scientific research objectives and have provided a wealth of documentation on reservoirs, wetlands, rivers, lakes and estuaries. ${ }^{106}$

Engineers and scientists agree on the indispensable value of the multidisciplinary and collaborative approach of the NPES. The abandonment of the programme in 1988 as a result of organisational restructuring was a tragedy for water research in South Africa. Prof Will Alexander, who participated actively in the IWE from the time of its inception to his retirement from DWA in 1984, comments thus on the repercussions of the termination of the programme:

All our hard work during the previous years of developing a multidisciplinary, multiinstitutional approach to the growing environmental problems in our country came to nothing. Slowly the institutions in the natural sciences developed a grain silo approach as they were forced to compete for research funding. ${ }^{107}$

\subsection{Dams and the Natal Parks Board}

Natal provincial authorities, most particularly the Natal Parks Board (NPB) and its scientists, played an important role in stimulating cooperation between DWA officials and aquatic scientists towards improved environmental management of the country's dams.

\footnotetext{
104. R.D. Walmsley. 'The role of multidisciplinary research programmes in the management of water resources' in Water $S A$ 18(2), 1992, pp. 195-201.

105 . J.H. O'Keeffe (Ed). Conservation of South African rivers, p. 15.

106 . R.D. Walmsley. 'The role of multidisciplinary research programmes in the management of water resources' in Water SA 18(2), 1992, pp. 195-201.

107. VVPA, Folder 4. 20120206 Alexander. p. 2 of pp. 1-6.
}

TD, 9(1), July 2013, pp. 51-80. 
A major example of this is the collaborative research programme around the Pongolapoort Dam. The NPB was concerned about the potential impacts of the dam on the Pongola Floodplain situated immediately downstream of the dam site. The annual inundation of the floodplain by summer floods reenergised a rich variance of ecosystems services that not only supported fish and animal life, but also a large community of people who depended on the floodplain for their livelihood. These floods would now be largely contained within the Pongolapoort Dam.

In 1967, NPB employee Mike Coke started research on the fish ecology of the floodplain lakes with a view of determining the effect of the dam. ${ }^{108}$ Coke's research subsequently underlined the importance of natural flooding to the life history of the fish species supported by the floodplain.

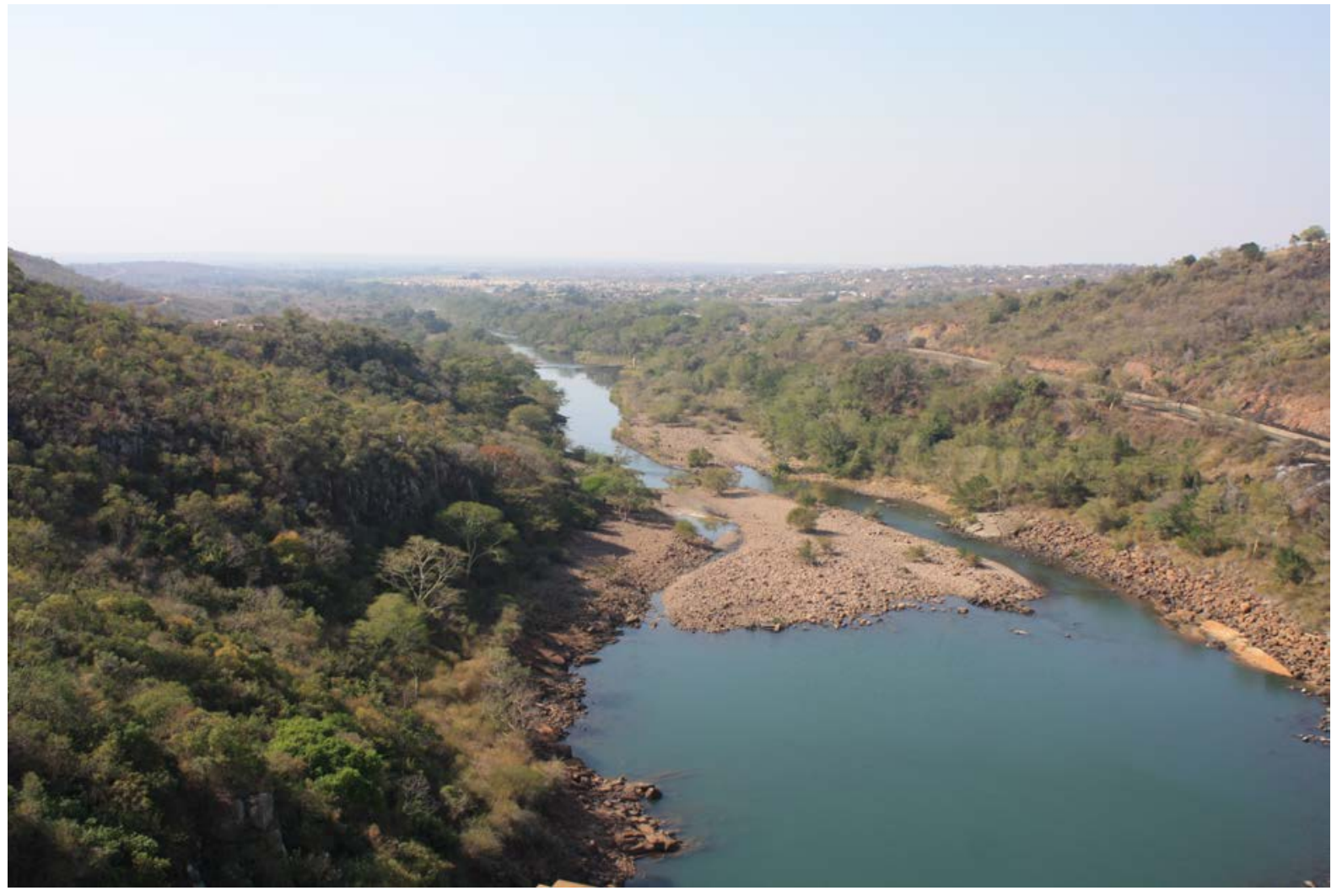

Illustration 13: The Pongola River downstream of the Pongolapoort Dam. ${ }^{109}$

The results of the research prompted the first meetings between the NPB and the DWA on mitigating the downstream effects of the Pongolapoort Dam. It was not the intention of the NPB to halt the construction of the dam, rather the parks board wanted to find a way of mitigating its effects on the downstream environment. ${ }^{110}$

The meetings were amicable - so much so that Coke and DWA Resident Engineer Roger Phélines, together with a colleague, went on to author a paper on the biological consequences

108. VVPA. Folder 4. 20121211 Coke. p.1 of pp. 1-4.

109 . Photograph: L. Van Vuuren, Pongola River, 15 Aug. 2012.

110 . VVPA. Folder 4. 20121211 Coke. p.1 of pp. 1-4. 
of the Pongolapoort Dam which was presented at the ICOLD conference in Madrid, Spain, in 1973. ${ }^{111}$ While DWA was sympathetic towards the need for environmental releases from Pongolapoort Dam, it required scientific proof as to how much water was required to sustain environmental processes on the floodplain. ${ }^{112}$ Still, the interaction between aquatic scientists and engineers on the issue was described as 'friendly, sympathetic and helpful'. ${ }^{113}$

In 1974, as a direct result of these discussions, the University of Natal established a research station on site at the Pongola floodplain as part of the IWE programme. The Pongola Floodplain Research Programme was the first comprehensive study in South Africa focusing on water releases for human and environmental benefit and remains unequalled in terms of scope and value. ${ }^{114}$

When comparing the benefits of water use for irrigation with the benefits of water use for ecosystem services, the latter came out tops, and the results provided the basis for recommendations on how to manage flow below the dam, which DWA accepted. Local water committees were subsequently spearheaded by the DWA to negotiate releases from Pongolapoort Dam, however, conflict of interest between, for example, fishermen and maize farmers, caused environmental releases to be placed on the back burner. ${ }^{115}$ No flood release date could apparently be found that suited all the roleplayers.

Despite the challenges of implementing the environmental releases the Pongola Floodplain Research Programme has had an enduring influence over the South African water sector. Project leader Professor Charles Breen sums up the benefits of the programme:

\section{[The research programme] set the platform for the DWA to begin to appreciate the importance of environmental flows and to collaborate with aquatic ecologists...It introduced people as integral parts of river ecosystems - a concept that would later become formulated as 'socio-ecological systems'. ${ }^{116}$}

In 1976, the NPB would play an important role again when it was appointed to undertake environmental impact assessment studies as part of the planned Mfolozi Dam. This was the first dam for which an EIA was taken prior to construction in South Africa. ${ }^{117}$

The Committee of Inquiry into the Ecological Aspects of a Dam in the Umfolozi River oversaw the EIA process. ${ }^{118}$ Representation on the committee included wildlife

111. R.F. Phélines, M. Coke and S.M. Nicol. 1973. Some biological consequences of the damming of the Pongolo river. (In_Proceedings of International Conference on Large Dams, Madrid, p. 175-190)

112. L. Van Vuuren. 'Pongolapoort Dam. Development steeped in controversy' in The Water Wheel 8(3), 2009, pp. 23-27.

113. VVPA. Folder 4. 20121211 Coke. p.1 of pp. 1-4.

114. L. Van Vuuren. 'Pongolapoort Dam. Development steeped in controversy' in The Water Wheel 8(3), 2009, pp. 23-27.

115 . VVPA. Folder 4. 20110725 Breen. p.2 of pp. 1-6.

116. VVPA. Folder 4. 20110725 Breen. pp.3-4 of pp. 1-6

117 . R.N. Porter. 'Damming the Umfolozi: Environmental impact assessment' in South African Journal of Science 73, 1977, p. 323.

118 R.N. Porter. 'Damming the Umfolozi: Environmental impact assessment' in South African Journal of Science 73, 1977, p. 323. 
preservationists, ecologists, planners and engineers. The positive experience from this process prompted DWA to subsequently pass a policy to voluntarily include EIA studies as part of all the department's bulk water resource development projects from $1980 .{ }^{119}$ A new division, namely Planning Services, was created within the DWA to oversee EIA studies.

\subsection{Drakensberg Pumped Storage Scheme}

Another water resources development project which helped to institutionalise environmental matters in the DWA and promote cooperation between engineers and scientists was the Drakensberg Pumped Storage Scheme. ${ }^{120}$ The project would change for ever the way in which large water resource development schemes were planned and executed within the department.

Located in the foothills of the Drakensberg complex, the Drakensberg Pumped Storage Scheme formed part of the second phase of the Tukhela-Vaal Transfer Scheme - the first phase of which had been approved in 1970 to augment water supply to what is now Gauteng. ${ }^{121}$

Concern from some of the owners of the farms that were to be expropriated for the project prompted the DWA to appoint an Environmental Committee for the Drakensberg Pumped Storage Scheme - the first such a committee to be formed for a water resource development project in South Africa. ${ }^{122}$ The committee's main objective was to identify - and propose ways to mitigate - major environmental impacts of the scheme. Specialists were employed for this purpose. ${ }^{123}$ While the DWA was willing to mitigate some of the effects of the scheme, this inter-basin transfer project was considered crucial and would be completed regardless of the environmental consequences. ${ }^{124}$

The Environmental Committee was chaired by the DWA, with representatives from the National Parks Board, Eskom, the Department of Forestry, Department of Planning, Department of Agricultural Technical Services, the NPB, and the Natal Town and Regional Planning Commission. ${ }^{125}$ The public's interest was represented by two members of a non-

119 DWA. Management of the water resources of the RSA, p. 6.45.

120. P. Roberts. 'Development and conservation go hand in hand at Water Affairs', The Civil Engineer in South Africa 26(9), 1984, pp. 417 and 419.

121. L. Van Vuuren. 'Thukhela-Vaal Transfer Scheme - Feeding the hungry heartland' in The Water Wheel 7(6), 2008, pp. 16-21.

122. C.P.R. Roberts and J.J. Erasmus. 'Environmental considerations of the Drakensberg Pumped Storage Scheme' in The Civil Engineer in South Africa 24(8), 1982, pp. 361-373 \& 455.

123 C.P.R. Roberts and J.J. Erasmus. 'Environmental considerations of the Drakensberg Pumped Storage Scheme' in The Civil Engineer in South Africa 24(8), 1982, pp. 361-373 \& 455.

124 C.P.R. Roberts and J.J. Erasmus. 'Environmental considerations of the Drakensberg Pumped Storage Scheme' in The Civil Engineer in South Africa 24(8), 1982, pp. 361-373 \& 455.

125 C.P.R. Roberts and J.J. Erasmus. 'Environmental considerations of the Drakensberg Pumped Storage Scheme' in The Civil Engineer in South Africa 24(8), 1982, pp. 361-373 \& 455. 
governmental organisation called the Council for the Habitat, a composite of various environmental organisations. The first meeting took place on 2 October, 1974.

Various specialist studies were subsequently undertaken (while the project was ongoing), the results of which were used to compile an environmental impact report in October 1975. It is important to note that the study included only the Drakensberg Pumped Storage Scheme and excluded other elements of phase two of the Thukhela-Vaal Transfer Scheme. No ecological studies were undertaken to determine potential effects on the river system. Rather the Committee focused on 'harmonising of site components, minimal disturbance of the natural environment and site restoration'. ${ }^{126}$

Again it took compromise and partnership between engineers and scientists to work out the best ways to minimise damage to the environment, particularly since there was no environmental laws to govern the process. Through this project DWA realised that managing dam construction with the environment in mind is not necessary an added burden on the engineer, but that it can have practical and financial advantages. ${ }^{127} \mathrm{~A}$ number of environmental measures taken, such as the use of grass rather than stone pitching on the downward slope of the Kilburn Dam, resulted in significant financial savings. ${ }^{128}$

A major long-term recommendation of the Drakensberg Pumped Storage Scheme Environmental Committee was that environmental committees should be established for every large water engineering project. Commenting on the changes within the department following the project, DWA Chief Engineer: Planning Services, Dr Paul Roberts, wrote in 1984:

It is now generally accepted within the Directorate of Water Affairs that environmental aspects must be taken into account in the planning, design, construction and budgeting for projects. Any resistance that there was has been overcome. ${ }^{129}$

\section{Discussion}

In line with international trends, South Africa's dam construction sector showed strong growth in environmental consciousness following the Second World War, starting with concerns regarding the quality of South Africa's water resources. Unlike the modern environmental movement in countries such as the USA improved environmental management of water resources was not as a result of public pressure but rather due to collaborative efforts between water engineers and aquatic scientists.

From the forties increased concern was express from various sectors to the deteriorating quality of South Africa's water resources. While local aquatic scientists were mostly focusing

\footnotetext{
126. P. Roberts. 'Development and conservation go hand in hand at Water Affairs', The Civil Engineer in South Africa 26(9), 1984, pp. 417 and 419.

127 C.P.R. Roberts and J.J. Erasmus. 'Environmental considerations of the Drakensberg Pumped Storage Scheme' in The Civil Engineer in South Africa 24(8), 1982, pp. 361-373 \& 455.

128 C.P.R. Roberts and J.J. Erasmus. 'Environmental considerations of the Drakensberg Pumped Storage Scheme' in The Civil Engineer in South Africa 24(8), 1982, pp. 361-373 \& 455.

129. P. Roberts. 'Development and conservation go hand in hand at Water Affairs', The Civil Engineer in South Africa 26(9), 1984, pp. 417 and 419.
} 
on identifying and classifying species in water systems, engineers were becoming increasingly environmentally conscious, realising the impact of infrastructure on water systems, and calling for more stringent regulations to curb pollution. Water quality issues were also being reported in dams, while dams themselves were seen as beneficial as they act as sinks to pollutants in water.

Even as the South African government became increasingly isolated from the seventies as a result of its apartheid policy, water engineering officials and local aquatic scientists maintained contact with their respective international communities through membership of professional bodies and publications in international journals. It was through these memberships that scientists and engineers became aware of growing international trends towards environmental consciousness in dam construction, which was then applied to the local sector.

While internationally, it was public conservation groups who placed increased pressure on authorities to implement environmental legislation from the sixties, which would eventually also pertain to the dam construction sector, in South Africa it was rather scientists who brought attention to the environmental impacts of specific dams in the country, while engineers themselves became increasingly concerned over the state of South Africa's rivers.

While South Africa's water resources had long been valued as a result of its relative scarcity, it was only once national and international freshwater research programmes grew local knowledge about the state and functioning of the country's freshwater systems that scientists and government officials were able to negotiate ways of how best to manage these systems in the absence of local legislation and public consultation, while meeting the growing human demand for water.

This shared concern between the different parties took an understanding and collaborative rather than a confrontational tone, and parties worked together voluntarily towards a state of compromise. The historically small size of the water sector also aided the fostering of professional and personal relationships between aquatic scientists and water engineers based on mutual respect, which stood them in good stead when negotiating ways to mitigate the environmental impact of dams.

The South African government, through the DWA and later the CSIR and WRC, expressed a willingness to invest in long-term, multidisciplinary, participative projects to garner the necessary scientific knowledge to improve decision-making to better manage the environmental impacts of dam developments. These research programmes were generally successful in fostering positive relationships between the different parties (i.e. DWA engineering officials and scientists). Although it did not curb the construction of dams, it further fostered environmental consciousness among the South African water engineering fraternity and laid the foundations for the environmental Reserve which would later become a cornerstone of South African water law, in which a percentage of water in each river has to be reserved to support ecological functions.

\section{Conclusion}

The results of the cooperation between aquatic scientists and engineers, the multidisciplinary research programmes, together with the outcome of early EIA studies, fed into the subsequent environmental-related decision-making around dams and DWA's decision to 
voluntary include environmental impact assessment and environmental committees as part of its bulk water resource development planning and construction process from 1980 - more than a decade before it became compulsory through national legislation.

The relationships built between DWA officials and the aquatic science community would stand the country's water sector in good stead after South Africa's democratisation in 1994 when the country's new water laws had to be negotiated, leading to one of the most progressive pieces of water legislation in the world in the form of the National Water Act (Act 36 of 1998).

\section{Bibliography}

\section{Primary sources}

Central Archive (SAB), Pretoria, Water Affairs Archive (WW)

SAB, WW, Pretoria, K1/8 Vol III 12. Letter to the Private Secretary to the Minister of Lands from the South African Association for the Advancement of Science, 2 February 1963.

SAB, WW, Pretoria, K1/8 Vol III 12. Response to the Letter to the Private Secretary to the Minister of Lands from the South African Association for the Advancement of Science, 26 February, 1964.

SAB, WW, Pretoria, K1/8 Vol III 12. Voorgestelde Hluhluwe Dam. Memorandum insake besware van verskeie instansies teen die aanbou van die dam.

SAB, WW, Pretoria, K23/1 Vol 392. Memorandum to Cabinet, No. 61/18 S.8/71 regarding South African members to the International Commission on Large Dams, undated.

SAB, WW, Pretoria, K52/4/1 435. Letter from Administrator of Natal to J.J. Fouché, Minister of Agricultural Technical Services and of Water Affairs, 7 July 1966 regarding abatement of pollution in rivers in Natal.

SAB, WW, Pretoria, K52/4/1 435. Water quality and abatement of pollution in Natal rivers, undated.

\section{Central Archive (SAB), Pretoria, Department of Cooperation and Development (SON)}

SAB, SON, Pretoria, D12/2/2/2/41 1537. Komitees, agendas, notules en verslae. Ondoersoek insake ekologiese aspekte van 'n dam in die Mfolozirivier. Minutes of meeting held on 25 March, 1976.

SAB, SON, Pretoria, D12/2/2/2/41 1537. Komitees, agendas, notules en verslae. Ondoersoek insake ekologiese aspekte van 'n dam in die Mfolozirivier. Minutes of meeting held on 22 October 1976.

SAB, SON, Pretoria, D12/2/2/2/41 1537. Komitees, agendas, notules en verslae. Ondoersoek insake ekologiese aspekte van 'n dam in die Mfolozirivier. Minutes of meeting held on 6 March 1978.

SAB, SON, Pretoria, D12/2/2/2/41 1537. Beplanningsafdeling, Department van Waterwese. Ondersoek en eliminasie van damterreine in die Mfoloziopvanggebied. Eerste verslag, November, 1977. 
Central Archive (SAB), Pretoria, Department of Health (GES)

SAB, GES, 107/33 2069. Committee of Enquiry on Bacterial and Chemicals Pollution of Water supplies.

Private archive

Van Vuuren Private Archive (VVPA), Email Correspondence File (ECF 1)

Alexander, W.J.R. Correspondence, 6 Feb. 2012.

Carter, C. Correspondence, 13 Jul. 2012

Breen, C. Correspondence, 26 Jul. 2011

Coke, M. Correspondence, 11 Dec., 2012

Day, J., Correspondence, 17 Feb. 2012

King, J. Correspondence, 13 Feb. 2012

Roberts, C.P.R. Correspondence, 30 May 2011

Walmsley, D. Correspondence, 10 Apr., 2012

Van Wyk, N. Correspondence, 12 Jul. 2012

Van Robbroeck, T.P.C. Correspondence, 10 Nov. 2010

Van Robbroeck T.P.C. Correspondence, 21 Jun. 2012.

Van Vuuren Private Archive (VVPA), Unpublished documents File 1

Alexander, W.J.R. 1991. Conservation of the water environment - is it attainable? (Paper delivered at Environmental Planning Professions Interdisciplinary Committee 1991 Conference on Water, on 16 May 1991.) Randburg (Unpublished.)

Alexander, W.J.R. 1976. Hydrology and the Water Environment. (Paper delivered at First Interdisciplinary Conference on Marine and Freshwater Research in Southern Africa from 5 to 10 July 1976.) Port Elizabeth. (Unpublished.)

Roberts, C.P.R. 1983. Environmental constraints on water resources development (Paper delivered at the Seventh Quinquinial Convention of the South African Institution of Civil Engineering 1983.) Cape Town. (Unpublished.)

Van Robbroeck, T.P.C. 1996. Reservoirs: Bane or Boon? (Geoffrey Binnie Lecture delivered at Ninth Biennial British Dam Society Conference on 11 September 1996.) York. 12 p. (Unpublished.)

Van Vuuren Private Archive (VVPA), Photographs File 1 (PF1)

VVPA, PF1, Dams

VVPA, PF1, Rivers

VVPA, PF1, National Library of South Africa

Secondary sources

Anon. 1971. 'The International Biological Programme', South African Medical Journal 45(45): 1277, November. 
Ashton, P.J. 2007. 'Riverine biodiversity conservation in South Africa: Current situation and future prospects', Aquatic Conservation: Marine and Freshwater Ecosystems 17(5): 441-445, July.

Ashton, P., Roux, D., Breen, C., Day, J., Mitchell, S., Seaman, M. \& Silberbauer, M. The freshwater science landscape in South Africa, 1900-2010. Overview of research topics, key individuals, institutional change and operating culture (Water Research Commission Nr. TT 530/12, Water Research Commission: Gezina, in print) $139 \mathrm{pp}$.

Beinart, W. 1984. 'Soil erosion, conservationism and ideas about development: A Southern African exploration, 1900-1960', Journal of Southern African Studies 11(1): 52-83, October

Beinart, W. and Coates, P. Environment and history. The taming of nature in the USA and South Africa. (Routledge: London and New York, 1995) 120 pp.

Beinart, W. The rise of conservation in South Africa - Settlers, livestock and the environment (Oxford University Press: Great Britain, 2003) 425 pp.

Brown, J.C. Water supply of South Africa and facilities for the storage of it. (Oliver \& Boyd: Edinburgh, 1877) 651 pp.

Bruwer, C.A. The economic impact of eutrophication. (Hydrological Research Institute Technical Report Nr. 94, Department of Water Affairs: Pretoria) 48 pp.

Day, J.H., Millard N.A.H. \& Broekhuysen, G.J. 1954. 'The ecology of South African estuaries Part IV: The St Lucia system', Transactions of the Royal Society of South Africa 34(1): 129-156.

Department of Environmental Affairs \& Tourism. South African Environment Outlook. A report on the state of the environment (Department of Environmental Affairs \& Tourism: Pretoria, 2006) $371 \mathrm{pp.}$

Department of Water Affairs. Water 75 (Erudita Publications, Johannesburg, n.d.) 227 pp.

Department of Water Affairs. Management of water resources of the Republic of South Africa. (CTP Book Printers, for the Government Printer: Cape Town, 1986).

Department of Water Affairs. Integrated water resource planning for South Africa. A situation analysis 2010. (Department of Water Affairs Report Nr. P RSA 000/00/12910, Department of Water Affairs, Pretoria, 2010) 40 pp.

Department of Water Affairs. Assessment of the ultimate potential and future marginal cost of water resources in South Africa. (Department of Water Affairs Report Nr. P RSA 000/00/12610, Department of Water Affairs, Pretoria, 2010) 178 pp.

Ecosystems Programmes (Compiler). Environmental research perspectives in South Africa. (South African National Scientific Programmes Report Nr. 6, CSIR: Pretoria, 1982) 46 pp.

Gandhi, A. 2003. 'Developing compliance and resistance: The state, transnational social movements and tribal peoples contesting India's Narmada project', Global Networks 3(4): 481-495.

Harvey, M.W.T. 1995. 'Battle for Dinosaur: Echo Park Dam and the birth of the modern wilderness movement', Montana: The Magazine of Western History 45(1), 1995: 32-45.

Hughes, G.R. and Coke, M. 2011. 'Roberts Sanderson [Bob] Crass (26 June 1921-13 January 2011)', African Journal of Aquatic Science 36(1): iii. 
Kanthack, F.E. 1910. 'Irrigation development in the Cape Colony: Past, present and future', Agricultural Journal of the Cape of Good Hope 36(3): 645-657, March.

King, J. \& Pienaar, H. (Eds). Sustainable use of South Africa's inland water (Water Research Commission Report Nr. TT 491/11, Water Research Commission: Gezina, 2011) 245 pp.

Kriel, J.P. Report of the Commission of Inquiry into the alleged threat to animal and plant life in St Lucia Lake (Government Printer: Pretoria, 1967) 371 pp.

Kriel, J.P. 1972 'Die siviele ingenieur in die veranderende wêreld', The Civil Engineer in South Africa 14(4): 141-151, January.

Lee, Y.B. 2013. 'Global capital, national development and transnational environmental activism: Conflict and the Three Gorges Dam', Journal of Contemporary Asia 43(1): 102-126.

Mackenzie, A.L. 1949. 'Presidential address', Minutes of Proceedings of the South African Institution of Civil Engineers 47: 6-26

McCully, P. Silenced rivers - The ecology and politics of large dams: enlarged and updated edition. (Zed Books: New York, 2007) 359 pp.

Middleton, B.J. \& Baily, A.K. Water resources of South Africa, 2005 study (WR2005) Executive summary, Version 1. (Water Research Commission Report Nr. TT 380/08, Water Research Commission: Gezina, 2009) 26 pp.

Middleton, B.J. \& Bailey, A.K. Water resources of South Africa, 2005 study (WR2005) Book of maps Version 1 (Water Research Commission Report Nr. TT 382/08, Water Research Commission: Gezina, 2009) 88 PP.

Noble, R.G. \& Hemens, J. Inland water ecosystems in South Africa - A review of research needs, a report of the Committee for Inland Water Ecosystems (South African National Scientific Programmes Report Nr. 34, CSIR: Pretoria, 1978) $160 \mathrm{pp}$.

Phelines, R.F., Coke, M., \& Nicol, S.M. 1973. Some biological consequences of the damming of the Pongolo river. (In_Proceedings of International Conference on Large Dams, Madrid, p. 175-190)

Porter, R.N. 1977. 'Damming the Umfolozi: Environmental impact assessment', South African Journal of Science 73: 323.

Republic of South Africa. Commission of Enquiry into water matters. (Report No. RP 34/1970z, Government Printer: Pretoria, 1970) 170 pp.

Roberts, C.P.R. 1981. Environmental considerations of water projects (In_Hattingh, W.H.J. ed. Water Year+10 and Then. Department of Water Affairs, Forestry \& Environmental Conservation: Pretoria, p.107-123)

Roberts, C.P.R. and J.J. Erasmus. 1982. 'Environmental considerations of the Drakensberg Pumped Storage Scheme', The Civil Engineer in South Africa 24(8): 361-373 \& 455, August.

Roberts, P. 1984. 'Development and conservation go hand in hand at Water Affairs', The Civil Engineer in South Africa 26(9): 417 and 419.

Robinson, M.C. 1989. 'The relationship between the Army Corps of Engineers and the environmental community, 1920-1969', Environmental Review 13(1): 1-41.

Shand, N. 1946. 'Presidential Address', Minutes of Proceedings of the South African Institution of Civil Engineers 44: 20-30.

Shand, N. 1953. The Transactions of the South African Institution of Civil Engineers 3(12): 381-391, December. 
Sills, D.L. 1975. 'The environmental movement and its critics', Human Ecology 3(1): 141.

Solomon, S. Water - The epic struggle for wealth, power and civilisation. (HarperCollins Publishers: New York, 2010) 608 pp.

South African National Committee on Large Dams. Large dams and water systems in South Africa (JP van der Walt \& Son: Pretoria, 1994) 256 pp.

South Africa. 1998. National Water Act 36 of 1998. Pretoria: Government Printer.

South Africa. 1998. National Environmental Management Act 107 of 1998. Pretoria: Government Printer.

Stander, G.J. 1952. 'The quality requirements of water for the maintenance of aquatic flora and fauna and for recreational purposes', The South African Industrial Chemist 6(6): 118-119, June.

Steyn, P. 2001. 'Environmental management in South Africa: twenty years of governmental response to the global challenge, 1972-1992', Historia 46(1): 2553, May.

Steyn, P. 2002. 'Popular environmental struggles in South Africa'. Historia 47(1): 125158, May.

Turpin, T. Dam. (Reaktion Books: London, 2008) 256 pp.

Turton, A.R., Meissner, R., Mampane, P.M. \& Seremo, O. A hydropolitical history of South Africa's international river basins. (Water Research Commission Report No. 1220/1/04, Water Research Commission: Gezina, 2004) 439 pp.

Union of South Africa. Report of the Committee of Enquiry concerning water laws of the Union (Report No. U.G. 11-1952, Government Printer: Pretoria, 1952) $122 \mathrm{pp}$.

Union of South Africa. Report of the Director of Irrigation for the period 1 April 1953 to 31 March 1954. (Report No. UG 60 - 1954, Government Printer: Pretoria, 1954)

Union of South Africa. Report on the proposed Hluhluwe River Government Water Work (Report No. WP U-1961, Government Printer: Pretoria, 1961)

Van Rooyen, J. Basson, T. Rossouw, J. Combrink, A. \& Schroder, J. 2011. 'Assessment of the ultimate potential and future marginal cost of water resources in South Africa', Civil Engineering 19(5): 12-18, June.

Van Vuuren, L. 2008. 'Thukela-Vaal Transfer Scheme - Feeding the hungry heartland', The Water Wheel 7(6): 16-21, November/December.

Van Vuuren, L. 2009. 'Dam busters', Africa Geographic (October): 46-47.

Van Vuuren, L. 2009. 'Pongolapoort Dam. Development steeped in controversy', The Water Wheel 8(3), May/June.

Van Vuuren, L. In the footsteps of giants - Exploring the history of South Africa's large dams. (Water Research Commission: Pretoria, 2012) 334 pp.

Walmsley, R.D. and Davies, B.R. 1991. 'An overview of water for environmental management' Water $S A$ 17(1): 67-76, January

Walmsley, R.D. 1992. 'The role of multidisciplinary research programmes in the management of water resources', Water $S A$ 18(2): 195-201, July.

World Commission on Dams. Dams and development - $A$ new framework for decisionmaking: The report of the World Commission on Dams: An overview. (Earthscan Publications: London, 2000). 356 pp. 


\section{Internet sources}

Department of Water Affairs. 2012. Dam Safety Office 2011/2012 Annual Report.http://www.dwaf.gov.za/dso/Documents/Annual\%20Report\%202011\%2012\%20fin.pdf Date of access: 7 Dec. 2012

International Commission on Large Dams (ICOLD). 2007. Dams and the World's Water.

http://www.icoldcigb.org/userfiles/files/PUBLICATIONS/others/DWWdamsandworldwater.PDF Date of access: 7 Mar. 2011.

ICOLD. Undated. Number of dams by country members. http://www.icoldcigb.org/GB/World_register/general_synthesis.asp?IDA=206 Date of access: 8 Jan. 2013.

Jinsheng, J.I.A. 2012. Summary Report as ICOLD President. Joint efforts for better development of dams and reservoirs, May 312012. http://www.icold2012kyoto.org/pdf/JiaOpening.pdf Date of access: 3 Feb. 2013.

Mallaby, S. 2004. NGOs: Fighting poverty, hurting the poor, Foreign Policy, 1 September.

http://www.foreignpolicy.com/articles/2004/09/01/ngos_fighting_poverty_hurti ng_the_poor Date of access: 19 Jun. 2012.

South African National Committee on Large Dams. 2009. South African list of large dams.

http://www.sancold.org.za/index.php?option=com_content\&view=article\&id=6 4\&Itemid=74 Date of access: 7 Jan. 2013.

United National Environment Programme. 2008. Vital Water Graphics: An Overview of the State of the World's Fresh and Marine Waters, Second Edition. http://www.unep.org/dewa/vitalwater/article32.html Date of access: 14 Mar. 2011.

United Nations.United Nations Environment Overview, Undated. http://www.un.org/en/globalissues/environment/ Date of access: 9 Jan. 2013.

World Wildlife Fund. Undated. Rivers at Risk, Dams and the Future of Freshwater Ecosystems.

Undated. http://awsassets.panda.org/downloads/riversatriskfullreport.pdf Date of access: 7 Mar. 2011. 